\section{Benzyladenine Increases Branching but Reduces Root Growth of Herbaceous Perennial Liners}

\author{
Mara Grossman, John Freeborn, Holly Scoggins, and Joyce Latimer ${ }^{1}$ \\ Department of Horticulture, Virginia Tech, 301 Saunders Hall, Blacksburg, \\ VA 24061
}

Additional index words. BA, Configure, plant growth regulators, Agastache, Gaura lindheimeri, Lavandula $\times$ intermedia, Leucanthemum $\times$ superbum, Salvia $\times$ sylvestris, WinRhizo, root surface area, root volume

\begin{abstract}
The objective of this study is to evaluate the branching effect of benzyladenine (BA) on herbaceous perennial plants during the production of rooted cuttings (liners) and to examine and quantify the root growth of these liners using multiple methods of root evaluation. Five crops were studied: Agastache Clayt. Ex Gronov. 'Purple Haze', Gaura lindheimeri Engelm. \& A. Gray 'Siskiyou Pink', Lavandula xintermedia Emeric ex Loisel. 'Provence', Leucanthemum $\times$ superbum (Bergmans ex J.W. Ingram) Bergmans ex Kent. 'Snowcap', and Salvia Xsylvestris L. (pro sp.) 'May Night'. After rooting but before transplant, BA was applied to rooted cuttings as four treatments: controls $\left(0 \mathrm{mg} \cdot \mathrm{L}^{-1}\right)$, one application of $300 \mathrm{mg} \cdot \mathrm{L}^{-1}$, two applications of $300 \mathrm{mg} \cdot \mathrm{L}^{-1}$, or one application of $600 \mathrm{mg} \cdot \mathrm{L}^{-1}$. Results varied by crop; all crops except Salvia had increased branching as measured as either increased lateral or basal branches and/or increased leaders at 3 to 4 weeks after initial treatment. Four crops showed reduced root growth, whereas Gaura was unaffected. Root dry weight was found to be highly correlated with root surface area and root volume. After transplant and growing out, branching of the finished plants was increased in Gaura and Lavandula, unaffected in Salvia and Leucanthemum, and decreased in Agastache. Treating rooted cuttings with BA before transplant increased branching but the effects were not long lasting, which suggests that additional applications at or after transplant may improve finished plant quality. Reductions in root growth noted in rooted cuttings did not affect the growth of finished plants. Chemical names: $\mathrm{N}$-(phenylmethyl)-1H-purine-6-amine (benzyladenine, BA).
\end{abstract}

To meet the challenges of producing plants for sale, growers frequently use plant growth regulators (PGRs) to control plant height, branching, and flowering. BA is a PGR that increases branching in floriculture crops when sprayed on containerized plants (Carey et al., 2009; Farris et al., 2009; Martin and Singletary, 1999). The addition of BA, a synthetic cytokinin, increases the ratio of cytokinin to auxin in the plant, disrupting apical dominance (Cline, 1991). This results in more basal and/or lateral branching and fuller plants. The effects of BA vary with cultivar: of 10 Hosta Tratt (Funkia K. Spreng; Niobe Salisb.) cultivars treated with 1250 to $3750 \mathrm{mg} \cdot \mathrm{L}^{-1}$ foliar sprays of BA, five cultivars

\footnotetext{
Received for publication 21 Dec. 2011. Accepted for publication 18 Apr. 2012.

Funding for this project was provided by Fine Americas, Inc. and the Virginia Nursery and Landscape Association.

We thank Conrad Fafard, Inc., and Aris Horticulture, Inc. for their support of floriculture research at Virginia Tech.

Mention of a trademark, proprietary product, or vendor does not constitute a guarantee or warranty of the product by Virginia Tech and does not imply its approval to the exclusion of other products or vendors that also may be suitable.

${ }^{1}$ To whom reprint requests should be addressed; e-mail jlatime@vt.edu.
}

had an increased number of offsets (Garner et al., 1997).

Chemical PGRs are often used during plug and rooted cutting (liner) production but must be used with care for efficacy and to prevent unwanted effects such as phytotoxicity or delayed flowering. These PGR applications are typically made $\approx 2$ to 4 weeks after liners have been transplanted, when plants are established and in active growth (Albrecht and Tayama, 1992). However, we are interested in testing the use of $\mathrm{BA}$ at an earlier stage of plant production on liners before transplant. Because liners are still in smaller cells, they are easier to treat with PGRs than plants that have already been transplanted into larger containers and less save money by spraying earlier in the plant production cycle. Some commercial producers of liners have reported reduced root mass in plants treated with BA (personal communication). BA has been shown to reduce root growth in in vitro Arabidopsis seedlings (Auer, 1996). Sedum leaf cuttings treated with $\mathrm{BA}$ at concentrations of 8 to $500 \mathrm{mg} \cdot \mathrm{L}^{-1}$ exhibited reduced root growth and increased shoot growth at all concentrations (Boe et al., 1972). Other research has shown BA has no effect on the root growth of treated plants (Khosh-Khui et al., 1978; Leclerc et al., 2006; Richards and Wilkinson, 1984). chemical is required per plant, so growers can
However, application of BA to unrooted cuttings of Verbena $\times$ hybrida Voss, which had already initiated adventitious root formation, had no effect on root growth, whereas low rates of BA $\left(30 \mathrm{mg} \cdot \mathrm{L}^{-1}\right)$ applied to cuttings before initiation of adventitious root formation increased root dry weight of liners at $12 \mathrm{~d}$ after treatment (Svenson, 1991).

The process of liner production has been divided into five stages: Stage 0, before arrival or harvest of cuttings; Stage 1, cutting arrival or harvest and sticking; Stage 2, callusing; Stage 3, root development; and Stage 4, toning the rooted cutting. During Stage 4 the roots are grown enough so that the root ball will hold together when pulled from the plug tray (Dole and Hamrick, 2006). The objective of this study is to evaluate the effects of the application of BA to herbaceous perennial plants during liner production, specifically during Stage 3, on root growth and shoot branching of the finished liners (Stage 4).

\section{Materials and Methods}

Five plant species were studied: Agastache 'Purple Haze', Gaura lindheimeri 'Siskiyou Pink', Lavandula Xintermedia 'Provence', Leucanthemum $\times$ superbum 'Snowcap', and Salvia $\times$ sylvestris 'May Night'. Plants arrived as unrooted cuttings, which were dipped for $10 \mathrm{sec}$ in $1500 \mathrm{mg} \cdot \mathrm{L}^{-1}$ indole-3-butyric acid (IBA) rooting hormone (Hortus IBA Water Soluble Salts 20\% IBA; Hortus USA Corp., New York, NY) as a basal treatment and stuck into 72 size (height $5.71 \mathrm{~cm}$, volume $35.4 \mathrm{~mL}$ ) trays filled with a peatmoss media with pine bark, perlite, and vermiculite $(45 \%$, $25 \%, 15 \%$, and $15 \%$, respectively; Fafard $3 \mathrm{~B}$; Conrad Fafard, Inc., Agawam, MA). Cuttings were allowed to root under mist with bottom heat at $22^{\circ} \mathrm{C}\left(72{ }^{\circ} \mathrm{F}\right)$. Twenty-seven to $34 \mathrm{~d}$ after sticking, depending on crop, plants were removed from mist and bottom heat. Cuttings received clear water under mist, but after removal from mist received $100 \mathrm{mg} \cdot \mathrm{L}^{-1}$ nitrogen with each irrigation using $20 \mathrm{~N}$ 4.4P-16.6K Peters Professional General Purpose fertilizer (The Scotts Co. LLC, Marysville, $\mathrm{OH})$.

Benzyladenine (Configure; Fine Americas, Inc., Walnut Creek, CA) was applied to liners at least $8 \mathrm{~h}$ after removal from mist. This was considered the Week 0 treatment. The BA treatments included: control $\left(0 \mathrm{mg} \cdot \mathrm{L}^{-1}\right)$, one application of $300 \mathrm{mg} \cdot \mathrm{L}^{-1}$, two applications of $300 \mathrm{mg} \cdot \mathrm{L}^{-1}$ (one application at Week 0 and the second application 2 weeks later), or one application of $600 \mathrm{mg} \cdot \mathrm{L}^{-1}$. Treatments were applied when roots from cuttings were evident on all four sides of the root ball but liners were not fully rooted and ready for transplant. Treatments were applied as foliar sprays of BA with a $\mathrm{CO}_{2}$ backpack sprayer (R\&D Sprayers, Inc., Opelousas, LA) applying $210 \mathrm{~mL} \cdot \mathrm{m}^{-2}$. Plants were grown in a double polyethylene greenhouse located in Blacksburg, VA (lat. $37.23^{\circ} \mathrm{N}$, long. $80.42^{\circ} \mathrm{W}$ ) from January through Apr. 2010. Greenhouse light levels averaged $17.8 \mathrm{~mol} \cdot \mathrm{m}^{-2} \cdot \mathrm{d}^{-1}$ and 
temperatures averaged $68.4^{\circ} \mathrm{F}$. The experimental setup was a completely randomized design with each plant species conducted as a separate experiment. Experimental units consisted of six plants in a single six-cell pack with four replications of the experimental unit per treatment for each of three destructive harvests for each crop. An additional set of replications was included for evaluation of how the liners grow out as described subsequently.

Data were collected at 0,2 , and 4 weeks after initial treatment (WAIT) on individual plants in each experimental unit (except at 0 , 2, and 3 WAIT on Agastache as a result of vigorous growth) and included plant height measured from the top of the container, average width, which was the average of the width measured at the widest point of the plant and again perpendicular to this point, number of branches, number of plants in flower, and phytotoxicity. Branches were counted if they were $2 \mathrm{~mm}$ long or longer. Based on growth habit, branches counted in Leucanthemum and Salvia were basal branches, which had no secondary laterals, and in Agastache, Gaura, and Lavandula, leaders (primary branches with secondary lateral branches) and secondary lateral branches were counted.

For root measurements and root and shoot dry weights, all six plants from the experimental unit (cell pack) were pooled. Media was washed off of roots by hand using a screen to prevent loss of roots. Roots were washed randomly by experimental unit. To better understand BA's effects on root growth and development, roots were scanned at each harvest using WinRhizo (Regent Instruments Inc., Quebec, Canada) and analyzed to determine root surface area and root volume. Root surface area and volume were determined by first washing all media off roots by hand and then scanning roots using WinRhizo. Root and shoot dry weights were determined after drying roots and shoots at $66^{\circ} \mathrm{C}\left(150^{\circ} \mathrm{F}\right)$ for $48 \mathrm{~h}$. Root:shoot dry weight ratio was calculated on an experimental unit basis using total shoot dry weight (shoot plus flowers, when present). Although the WinRhizo allowed detailed measurement of root growth characteristics, the process was very time-consuming. To facilitate future research, we evaluated the correlation between root dry weight and the root surface area and root volume data from the WinRhizo analysis. Root dry weights of BA-treated and untreated plants at all times of measurement $(0,2$, and 3 to 4 WAIT) were compared with root volume and root surface area for each species studied.

After data were collected at 4 WAIT, eight plants of each treatment were randomly selected from the remaining replications, potted into quart-sized plastic pots $(1.1 \mathrm{~L})$ filled with Fafard 3B medium, and grown out for a period of 4 additional weeks to assess liner treatment effects on the finished plant. These plants were arranged as single plant replications in a completely randomized design for each crop. On finished plants, data measurements included height, width, and numbers of leaders and lateral or basal branches as applicable and the number of plants flowering.

Data were analyzed by analysis of variance and subjected to least significant difference means separation $(P \leq 0.05)$ using SAS Version 9.2 by SAS Institute Inc. (Cary, NC) and JMP®9.0 (C2010 SAS Institute Inc. Correlation of root dry weight to root volume and surface area was performed by bivariate analysis and linear regression in JMP ${ }^{\circledR 9} 9.0$.

\section{Results}

In all plants, measurements were taken at 0 WAIT to ensure uniformity. At this time, there were no significant differences between control plants and plants treated with BA in plant height, width, numbers of leaders and lateral branches or basal branches, root or shoot dry weights, root surface area, root volume, or root:shoot ratio (data not presented). None of the cuttings were flowering. No significant phytotoxicity was noted in plants at any data collection times.

Agastache 'Purple Haze'. At 2 WAIT, all plants treated with BA showed significant increases in the number of lateral branches as compared with control plants (8.8 to 12.4 vs. 2.5$)$, although there were no significant differences in height, width, the number of leaders, or shoot dry weight (data not presented). Root surface area and volume measurements were lower than control plants only in plants treated with one application of $300 \mathrm{mg} \cdot \mathrm{L}^{-1}$, whereas plants assigned to the two applications of $300 \mathrm{mg} \cdot \mathrm{L}^{-1} \mathrm{BA}$ had greater root volume than controls. Because these plants had not yet been treated the second time, this suggests significant variability in the root growth response. There were no significant differences in root dry weights but the root:shoot ratio was significantly lower than controls in plants treated with one application of either 300 or $600 \mathrm{mg} \cdot \mathrm{L}^{-1} \mathrm{BA}$ (data not presented).

At 3 WAIT, although plant height, width, and number of leaders were unaffected, all BA-treated Agastache liners showed an increase in the number of lateral branches as compared with control plants (Table 1). Although shoot dry weight was unaffected, all BA-treated plants had less root dry weight, root surface area, and root volume than control plants, resulting in lower root:shoot ratios relative to control plants. Root growth of Agastache liners treated with two applications of $300 \mathrm{mg} \cdot \mathrm{L}^{-1}$ or one application of $600 \mathrm{mg} \cdot \mathrm{L}^{-1}$ had the greatest reductions in root dry weight.

On finished plants, height and width of BA-treated plants were not different from control plants but plants treated at the higher BA concentrations (two applications of $300 \mathrm{mg} \cdot \mathrm{L}^{-1}$ or one application of $600 \mathrm{mg} \cdot \mathrm{L}^{-1}$ ) had fewer leaders and lateral branches than control plants or those treated with a single application of $300 \mathrm{mg} \cdot \mathrm{L}^{-1} \mathrm{BA}$ (Table 2). There were no differences between BA-treated and untreated plants in the number of plants flowering (data not presented).
Agastache liners treated with BA showed increased lateral branches and decreased root growth at 3 WAIT; however, finished plants treated with the higher treatment concentrations in the liner stage had fewer lateral branches.

Gaura lindheimeri 'Siskiyou Pink'. At 2 WAIT, BA-treated Gaura liners showed no significant differences in height or numbers of leaders or lateral branches as compared with controls (data not presented). Shoot dry weight increased in liners treated with two applications of $300 \mathrm{mg} \cdot \mathrm{L}^{-1} \mathrm{BA}$ or one application of $600 \mathrm{mg} \cdot \mathrm{L}^{-1} \mathrm{BA}$ when compared with control liners (data not presented). Root dry weight, surface area, and volume were greater than controls in plants treated with one application of $300 \mathrm{mg} \cdot \mathrm{L}^{-1} \mathrm{BA}$ (data not presented). Root:shoot ratio was greater than controls in plants treated with one or two applications of $300 \mathrm{mg} \cdot \mathrm{L}^{-1} \mathrm{BA}$. Again, because the second application of the $300 \mathrm{mg} \cdot \mathrm{L}^{-1}$ BA had not yet been applied, there is some variability in liner response to the $300 \mathrm{mg} \cdot \mathrm{L}^{-1}$ BA treatment.

At 4 WAIT, BA-treated Gaura liners showed no significant differences in plant height or width as compared with the control plants (Table 1). However, all Gaura liners treated with BA had more leaders than the untreated control plants; the number of lateral branches on these shoots at this time was not different from control plants. Shoot dry weight was greater in BA-treated plants than in control plants (Table 1). Root growth was unaffected by BA treatment; there were no significant differences in root dry weight, root surface area, root volume, or root:shoot ratio compared with control plants. In Gaura liners, treatment with BA resulted in more shoot growth at 4 WAIT without significantly affecting root growth.

In finished Gaura plants, there were no significant treatment effects on plant height or width (Table 2). However, all plants treated with BA had significant increases in the numbers of leaders and lateral branches relative to the untreated control plants. The branching effects of BA in Gaura liners were persistent in the finished plants. There were no differences in the number of plants in flower between BA-treated and untreated plants (data not presented).

Lavandula xintermedia 'Provence'. For Lavandula at 2 WAIT, there were no significant differences in BA-treated plants in plant height, width, number of leaders, number of lateral branches, or shoot dry weight as compared with control plants (data not presented). All liners treated with BA had significant reductions in root dry weight, root surface area, root volume, and root:shoot ratio at 2 WAIT as compared with control liners (data not presented).

At 4 WAIT, Lavandula liners treated with two applications of $300 \mathrm{mg} \cdot \mathrm{L}^{-1}$ or one application of $600 \mathrm{mg} \cdot \mathrm{L}^{-1} \mathrm{BA}$ were significantly taller than untreated controls (Table 1). Width was significantly increased only with two applications of $300 \mathrm{mg} \cdot \mathrm{L}^{-1} \mathrm{BA}$. Only liners treated with one application of $600 \mathrm{mg} \cdot \mathrm{L}^{-1}$ 
Table 1. Liner root and shoot measurements of Agastache 'Purple Haze', Gaura lindheimeri ‘Siskiyou Pink', Lavandula ×intermedia 'Provence', Leucanthemum ×superbum 'Snowcap', and Salvia $\times$ sylvestris 'May Night' at 4 weeks after initial treatment with benzyladenine (BA). ${ }^{\text {' }}$

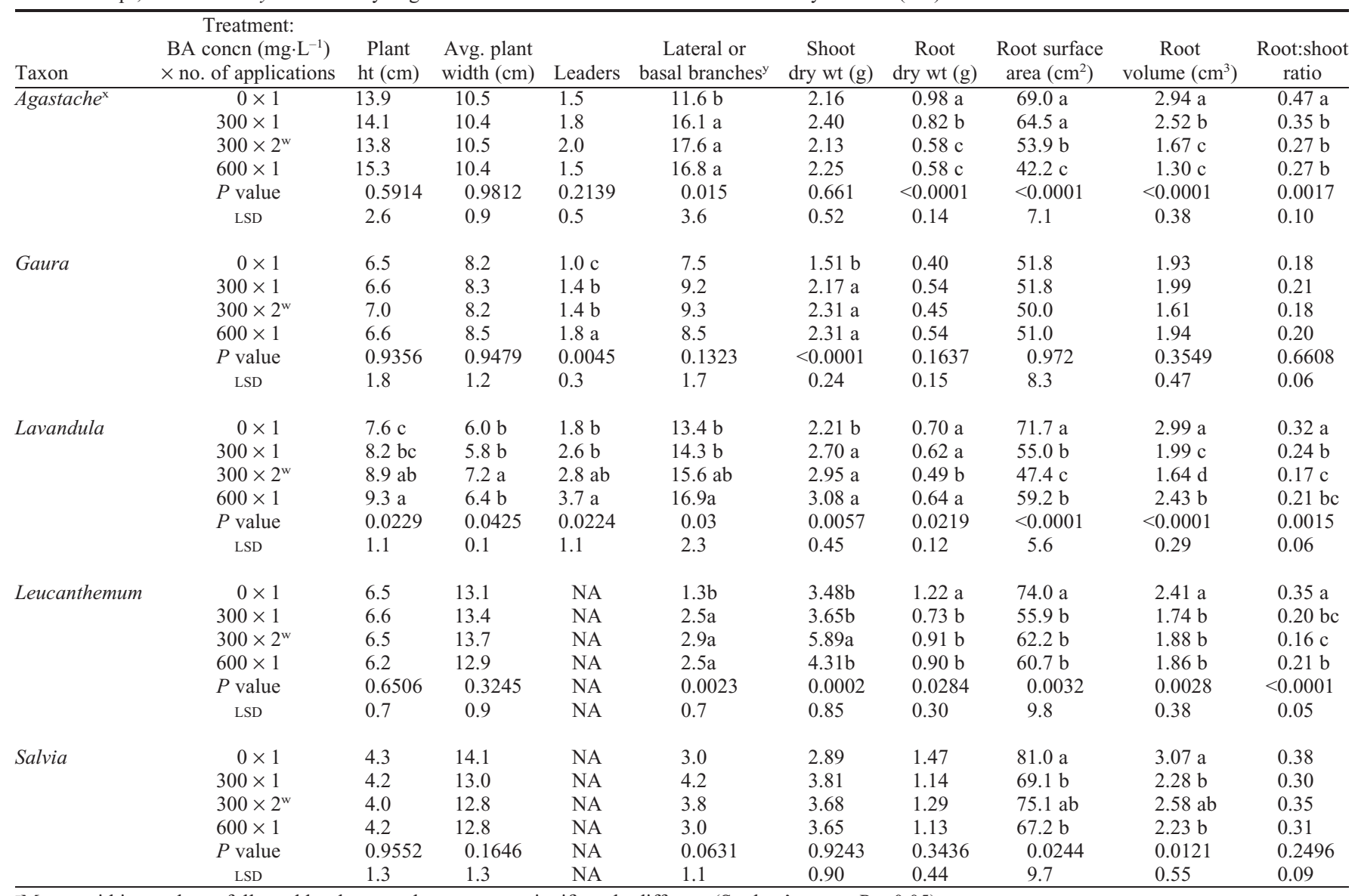

${ }^{\mathrm{z}}$ Means within a column followed by the same letter are not significantly different (Student's $t$ test, $P<0.05$ ).

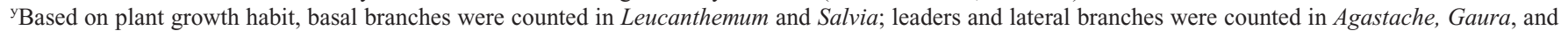
Lavandula.

${ }^{\mathrm{x}}$ Measurements were taken on Agastache at 3 weeks after initial treatment as a result of vigorous growth.

${ }^{w}$ The second application of $300 \mathrm{mg} \cdot \mathrm{L}^{-1} \mathrm{BA}$ was applied 2 weeks after the first treatment.

LSD $=$ least significant difference; NA = not applicable.

BA had increased numbers of leaders and lateral branches as compared with control plants. Shoot dry weight increased with all BA treatments as compared with control liners. Root surface area, volume, and root:shoot ratio were reduced in all BA-treated Lavandula liners relative to controls at 4 WAIT, although root dry weight was significantly reduced only with two applications of $300 \mathrm{mg} \cdot \mathrm{L}^{-1} \mathrm{BA}$.

Finished Lavandula plants treated with multiple applications of BA were taller than control plants, but two applications of $300 \mathrm{mg} \cdot \mathrm{L}^{-1}$ or a single application of $600 \mathrm{mg} \cdot \mathrm{L}^{-1} \mathrm{BA}$ reduced plant width as compared with control plants (Table 2). Plants treated with two applications of $300 \mathrm{mg} \cdot \mathrm{L}^{-1} \mathrm{BA}$ had greater numbers of leaders and lateral branches than control plants. Lavandula did not flower during this study.

At 4 WAIT, BA-treated Lavandula liners showed increased numbers of leaders and lateral branches at the highest BA concentration and decreased root growth with all BA treatments; however, only plants treated with two applications of $300 \mathrm{mg} \cdot \mathrm{L}^{-1}$ showed persistent increases in branching in finished plants.
Leucanthemum $\times$ superbum 'Snowcap'. At 2 WAIT, Leucanthemum liners treated with BA were not significantly different from controls in the shoot measurements of plant height, width, number of basal branches, or shoot dry weight (data not presented). However, root dry weight, root surface area, and root volume were significantly less in plants treated with BA as compared with controls (data not presented). Liners treated with one application of either $300 \mathrm{mg} \cdot \mathrm{L}^{-1} \mathrm{BA}$ or $600 \mathrm{mg} \cdot \mathrm{L}^{-1} \mathrm{BA}$ had significantly lower root: shoot ratios as compared with control liners (data not presented).

At 4 WAIT, Leucanthemum liners treated with BA showed no significant differences in plant height or width relative to controls (Table 1). However, the number of basal branches was significantly increased with all BA treatments as compared with control liners. Shoot dry weight was significantly increased only with two applications of $300 \mathrm{mg} \cdot \mathrm{L}^{-1} \mathrm{BA}$. Root growth was significantly affected by BA; root dry weight, root surface area, root volume, and root:shoot ratio were significantly decreased in all BA-treated liners as compared with controls.
Finished Leucanthemum plants treated with BA showed no significant differences in plant height but plants treated with one application of $600 \mathrm{mg} \cdot \mathrm{L}^{-1}$ had a $14 \%$ reduction in width relative to control plants (Table 2). The number of basal branches on finished plants was unaffected by BA treatments as compared with control plants. Leucanthemum did not flower during this study.

Leucanthemum liners treated with BA had significantly greater basal branching and decreased root growth at 4 weeks after initial treatment when compared with controls, although this branching improvement was no longer evident in the finished plants.

Salvia ×sylvestris 'May Night'. At 2 WAIT, BA-treated Salvia liners showed no significant differences in plant height, width, number of basal branches, or shoot dry weight when compared with control plants (data not presented). Root dry weight, surface area, and volume were significantly reduced in all BAtreated liners as compared with controls. There was no significant difference in root:shoot ratio in BA-treated liners relative to control plants (data not presented). 
Table 2. Shoot measurements of Agastache 'Purple Haze', Gaura lindheimeri 'Siskiyou Pink', Lavandula $\times$ intermedia 'Provence', Leucanthemum $\times$ superbum 'Snowcap', and Salvia $\times$ sylvestris 'May Night' at 4 weeks after transplant, 8 weeks after initial treatment with benzyladenine (BA). ${ }^{\mathrm{z}}$

\begin{tabular}{|c|c|c|c|c|c|}
\hline Taxon & $\begin{array}{c}\text { Treatment: } \\
\text { BA concn }\left(\mathrm{mg} \cdot \mathrm{L}^{-1}\right) \\
\times \text { no. of applications }\end{array}$ & Plant ht $(\mathrm{cm})$ & $\begin{array}{l}\text { Avg. plant } \\
\text { width }(\mathrm{cm})\end{array}$ & Leaders & $\begin{array}{c}\text { Lateral or } \\
\text { basal branches }\end{array}$ \\
\hline \multirow[t]{6}{*}{ Agastache } & $0 \times 1$ & $31.9 \mathrm{ab}$ & $20.1 \mathrm{a}$ & $9.4 \mathrm{a}$ & $44.6 \mathrm{a}$ \\
\hline & $300 \times 1$ & $29.4 \mathrm{~b}$ & $21.0 \mathrm{a}$ & $9.9 \mathrm{a}$ & $45.4 \mathrm{a}$ \\
\hline & $300 \times 2^{x}$ & $33.3 \mathrm{a}$ & $20.4 \mathrm{a}$ & $7.4 \mathrm{~b}$ & $37.5 \mathrm{~b}$ \\
\hline & $600 \times 1$ & $28.8 \mathrm{~b}$ & $15.8 \mathrm{~b}$ & $7.0 \mathrm{~b}$ & $31.8 \mathrm{~b}$ \\
\hline & $P$ value & 0.0231 & 0.0097 & 0.0057 & 0.0009 \\
\hline & LSD & 3.2 & 3.2 & 1.8 & 6.9 \\
\hline \multirow[t]{6}{*}{ Gaura } & $0 \times 1$ & 4.5 & 27.9 & $1.8 \mathrm{c}$ & $11.1 \mathrm{~b}$ \\
\hline & $300 \times 1$ & 5.8 & 28.7 & $2.9 \mathrm{~b}$ & $19.0 \mathrm{a}$ \\
\hline & $300 \times 2^{x}$ & 5.8 & 26.0 & $4.0 \mathrm{a}$ & $19.1 \mathrm{a}$ \\
\hline & $600 \times 1$ & 6.3 & 27.8 & $3.5 \mathrm{ab}$ & $20.5 \mathrm{a}$ \\
\hline & $P$ value & 0.5864 & 0.4212 & 0.0085 & 0.0003 \\
\hline & LSD & 2.7 & 3.3 & 1.0 & 5.7 \\
\hline \multirow[t]{6}{*}{ Lavandula } & $0 \times 1$ & $10.2 \mathrm{~b}$ & $11.6 \mathrm{a}$ & $3.6 \mathrm{a}$ & $24.8 \mathrm{~b}$ \\
\hline & $300 \times 1$ & $10.8 \mathrm{ab}$ & $11.4 \mathrm{ab}$ & $3.4 \mathrm{a}$ & $24.8 \mathrm{~b}$ \\
\hline & $300 \times 2^{x}$ & $11.4 \mathrm{a}$ & $10.7 b c$ & $6.0 \mathrm{~b}$ & $45.8 \mathrm{a}$ \\
\hline & $600 \times 1$ & $10.8 \mathrm{ab}$ & $9.8 \mathrm{c}$ & $3.0 \mathrm{a}$ & $27.8 \mathrm{~b}$ \\
\hline & $P$ value & 0.0409 & 0.0008 & $<0.0001$ & 0.0015 \\
\hline & LSD & 0.8 & 0.851 & 1.5 & 5.9 \\
\hline \multirow[t]{6}{*}{ Leucanthemum } & $0 \times 1$ & 4.4 & $19.0 \mathrm{a}$ & NA & 15.5 \\
\hline & $300 \times 1$ & 4.5 & $18.4 \mathrm{a}$ & NA & 15.5 \\
\hline & $300 \times 2^{x}$ & 4.3 & $17.8 \mathrm{a}$ & NA & 15.8 \\
\hline & $600 \times 1$ & 4.3 & $16.4 \mathrm{~b}$ & NA & 16.3 \\
\hline & $P$ value & 0.9288 & 0.0012 & NA & 0.9531 \\
\hline & LSD & 0.9 & 1.2 & NA & 3.1 \\
\hline \multirow[t]{6}{*}{ Salvia } & $0 \times 1$ & 6.3 & 20.6 & NA & 6.3 \\
\hline & $300 \times 1$ & 5.9 & 19.0 & NA & 5.9 \\
\hline & $300 \times 2^{x}$ & 6.4 & 20.1 & NA & 6.4 \\
\hline & $600 \times 1$ & 5.4 & 18.6 & NA & 5.4 \\
\hline & $P$ value & 0.4006 & 0.17 & NA & 0.7565 \\
\hline & LSD & 1.4 & 2.0 & NA & 1.4 \\
\hline
\end{tabular}

${ }^{\mathrm{z}}$ Means within a column followed by the same letter are not significantly different (Student's $t$ test, $P<0.05)$.

${ }^{y}$ Based on plant growth habit, basal branches were counted in Leucanthemum and Salvia; leaders and lateral branches were counted in Agastache, Gaura, and Lavandula.

${ }^{x}$ The second application of $300 \mathrm{mg} \cdot \mathrm{L}^{-1} \mathrm{BA}$ was applied 2 weeks after the first treatment.

LSD $=$ least significant difference; NA $=$ not applicable.

At 4 WAIT, BA-treated Salvia liners had no significant differences in plant height, width, number of basal branches, or shoot or root dry weight relative to control liners (Table 1). However, root surface area and root volume were significantly reduced in liners treated with a single application of $300 \mathrm{mg} \cdot \mathrm{L}^{-1}$ or $600 \mathrm{mg} \cdot \mathrm{L}^{-1} \mathrm{BA}$ as compared with those of control liners.

Finished Salvia plants treated with BA showed no significant differences in plant height, width, or number of basal branches when compared with control plants (Table 2). Salvia did not flower during this study.

At 4 WAIT, BA treatment did not significantly increase branching of Salvia liners, although root surface area and volume decreased with one application of 300 or $600 \mathrm{mg} \cdot \mathrm{L}^{-1} \mathrm{BA}$. After transplant and grow out, there were no differences in the finished Salvia plants.

Correlations of root measurements. Root growth of liners is important to growers because adequate roots are necessary to ensure plant establishment after transplant. Because our liners had reasonable root initiation (Stage 3) before BA treatment, we wanted branches and/or leaders, which are measures of a plant's fullness, showed significant increases in BA-treated liners of all crops studied except Salvia compared with untreated plants. The branching results are similar to those of Martin and Singletary (1999) where 18 herbaceous perennials were screened for response to 1000,2000 , or $4000 \mathrm{mg} \cdot \mathrm{L}^{-1} \mathrm{BA}$ applied as a foliar spray after transplant; the majority $(89 \%)$ of the BA-treated plants developed significantly more offshoots than untreated controls but root growth was not assessed. In their study, no additional branching was seen in the higher two concentrations as compared with $1000 \mathrm{mg} \cdot \mathrm{L}^{-1}$ BA (Martin and Singletary, 1999), and later studies have used lower concentrations with good success (Carey et al., 2008; Farris et al., 2009). Drench or foliar application of BA at concentrations from 250 to $2000 \mathrm{mg} \cdot \mathrm{L}^{-1}$ increased vegetative shoots, reproductive shoots, and flower buds in Coreopsis verticillata L. 'Moonbeam'; however, plants treated with 1000 or $2000 \mathrm{mg} \cdot \mathrm{L}^{-1}$ BA had persistent symptoms of phytotoxicity and a 19-d delay in flowering as compared with only transient phytotoxicity and a 7-d delay in flowering in plants treated with 250 or $500 \mathrm{mg} \cdot \mathrm{L}^{-1}$ BA (Farris et al., 2009).

After growing out for 4 weeks, only finished plants of Gaura and Lavandula showed persistent improvements in branching as a result of the BA treatment. Finished Salvia and Leucanthemum plants showed no significant branching effects after growing out, whereas Agastache plants showed less branching at two treatment concentrations. The persistence of the branching effect of BA varied with species, as seen in results by Latimer and Freeborn (2009) in which the increases in branching in herbaceous perennials treated with foliar sprays of $600 \mathrm{mg} \cdot \mathrm{L}^{-1}$ BA after transplant to quart size pots ranged from 2 weeks in Leucanthemum $\times$ 'Alaska' to 6 weeks in Euphorbia 'Chameleon'. Plants metabolize BA at differing rates; even different cultivars of the same species are different (Auer et al., 1992). Because plants metabolize BA quickly, in $\approx 10 \mathrm{~d}$ (Carey et al., 2009), multiple applications over the production cycle may be more effective than a single application.

Plant growth regulators affect root growth as well as shoot growth in plants (Basra, 2000). Low concentrations of BA, $30 \mathrm{mg} \cdot \mathrm{L}^{-1}$, applied to unrooted cuttings as foliar sprays immediately or $12 \mathrm{~h}$ after sticking, increased root dry weight in Verbena evaluated $12 \mathrm{~d}$ later when compared with untreated controls, whereas $300 \mathrm{mg} \mathrm{L}^{-1} \mathrm{BA}$ tended to reduce root dry weight (Svenson, 1991). The multiple applications and higher rate used in our studies had greater effects on root dry weight. Furthermore, Svenson (1991) found that BA applications later than $48 \mathrm{~h}$ after sticking had no effect on the cuttings. BA at 400,800 , or $1200 \mathrm{mg} \mathrm{L}^{-1}$ applied to seedlings of four cultivars of Coleus blumei benth after transplant increased the number of branches but did not affect root growth (Khosh-Khui et al., 1978). Similarly, in BA-treated Hemerocallis 'Happy Returns', the number of divisions per 

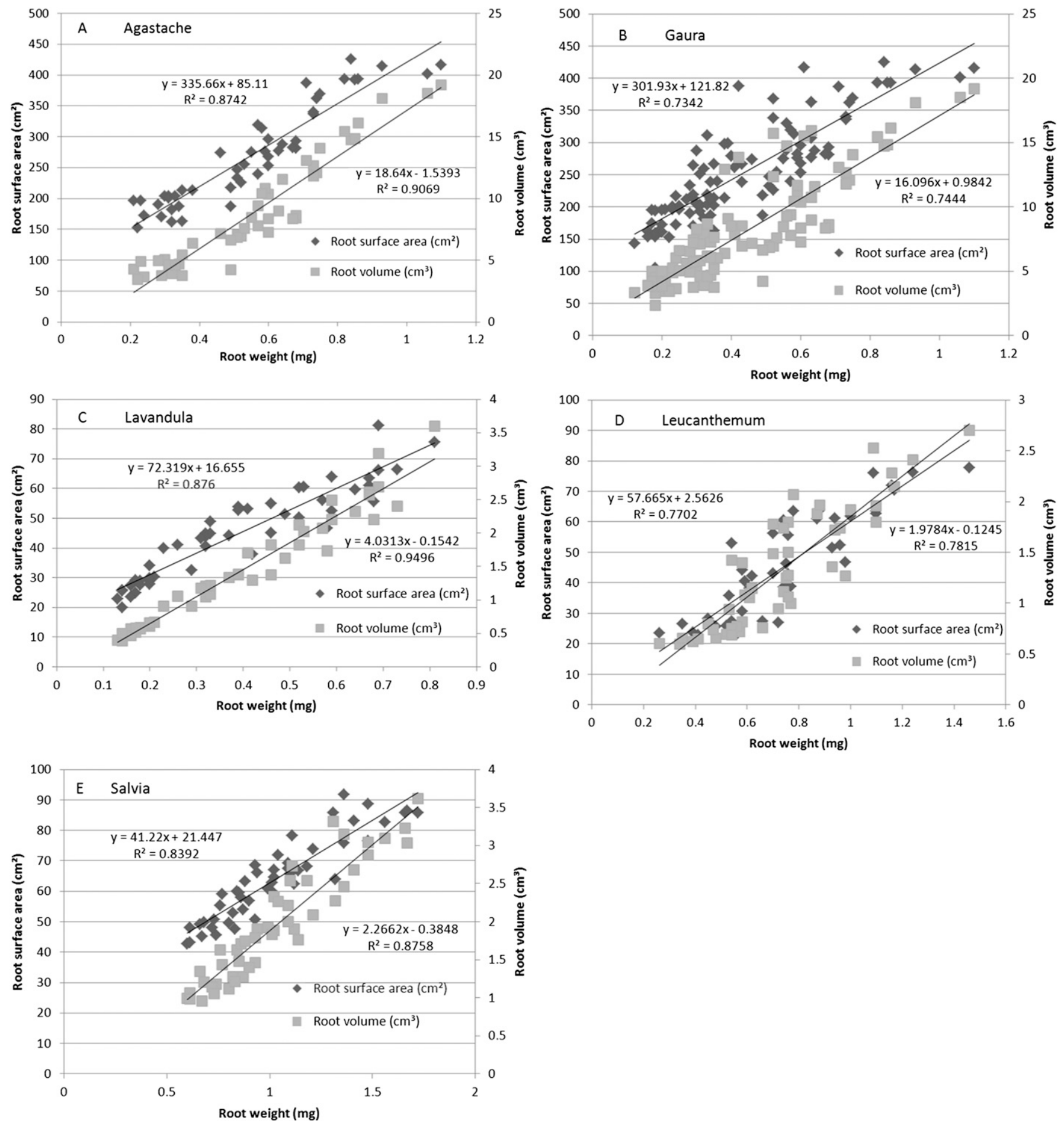

Fig. 1. The correlation between root dry weight ( $\mathrm{mg}$, horizontal axis) and root surface area $\left(\mathrm{cm}^{2}\right.$, left axis) and between root dry weight and root volume $\left(\mathrm{cm}^{3}\right.$, right axis) at 0, 2, and 4 weeks after initial treatment (WAIT) (0,2, and 3 WAIT for Agastache) of (A) Agastache 'Purple Haze', (B) Gaura lindheimeri 'Siskiyou Pink', (C) Lavandula ×intermedia 'Provence', (D) Leucanthemum $\times$ superbum 'Snowcap', and (E) Salvia $\times$ sylvestris 'May Night' along with the regression functions and coefficient of determination $\left(r^{2} ; P<0.0001\right)$. Roots were analyzed using WinRhizo (Regent Instruments Inc., Quebec, Canada). Solid line represents linear regression.

plant was increased, whereas root fresh weight was unaffected (Leclerc et al., 2006). In their review of the role of cytokinins in adventitious root formation, Van Staden and Harty (1988) concluded that root initiation and root elongation are affected differently by exogenous cytokinins in that root initiation is more sensitive to inhibition by high levels of cytokinins than is root elongation. In our studies,
BA was applied during root elongation. Root measurements showed significant reductions in BA-treated Agastache, Lavandula, Leucanthemum, and Salvia liners at 4 WAIT (3 WAIT for Agastache). However, these plants did not show any reduced shoot measurements at this time. Thus, these reductions in root growth did not appear to affect shoot growth. Root:shoot ratio decreased in BA-treated
Agastache, Lavandula, and Leucanthemum liners at 4 WAIT (3 WAIT for Agastache). In our studies, BA seemed to encourage shoot growth at the expense of root growth.

Root surface area and volume measurements were highly correlated with root dry weight. These results are similar to those of McPhee (2005) in a study of Pisum sativum L. seedlings in which root dry weight was 
highly correlated with root volume and root length. Because the intent of our study was to study the effects of BA on the root and shoot growth of liners, root and shoot dry weight measurements were not taken for plants after transplant and growing out for an additional 4 weeks; however, these measurements would be helpful in future studies in understanding the effects of BA on plants as they grow to marketable size.

Treating plants with BA as liners before transplant resulted in more branching, which produced a liner that appeared fuller at an earlier stage of growth. However, in most of the crops tested, branching of the untreated liners eventually matched that of plants treated with BA, suggesting that multiple applications of BA may be beneficial. Root growth of liners of some crops was reduced by BA treatments but this reduction did not seem to influence the overall growth of the finished plants. In summary, herbaceous perennial plant liner producers may use BA to increase liner size and branching without a major impact on subsequent plant establishment. Finished plant producers should consider applying BA again on responsive plants either in the flat before transplanting or in the finishing container shortly after transplanting.

\section{Literature Cited}

Albrecht, M.L. and H.K. Tayama. 1992. Tips on the use of chemical growth regulators on floriculture crops. Ohio Florists' Assoc., Columbus, $\mathrm{OH}$.

Auer, C.A. 1996. Cytokinin inhibition of Arabidopsis root growth: An examination of genotype, cytokinin activity, and $\mathrm{N}^{6}$-benzyladenine metabolism. J. Plant Growth Regul. 15:201-206.

Auer, C.A., J.D. Cohen, M. Laloue, and T.J. Cooke. 1992. Comparison of benzyl adenine metabolism in two Petunia hybrida lines differing in shoot organogenesis. Plant Physiol. 96:10351041.

Basra, A.S. 2000. Plant growth regulators in agriculture and horticulture: Their role and commercial uses. Food Products Press, Binghamton, NY.

Boe, A.A., R.B. Stewart, and T.J. Banko. 1972. Effects of growth regulators on root and shoot development on sedum leaf cuttings. HortScience 7:404-405.

Carey, D., W. Buhler, and B. Whipker. 2009. Stimulating plant growth. Greenhouse Product News 9:20, 22, 24.

Carey, D., B. Whipker, I. McCall, and W. Buhler. 2008. Cytokinin based PGR affects growth of vegetative petunia. Proc. Plant Growth Regulat. Soc. Amer. 35:85-89.

Cline, M.G. 1991. Apical dominance. Bot. Rev. 57:318-358

Dole, J.M. and D.J. Hamrick. 2006. Propagation basics, p. 9. In: Dole, J.M. and J.L. Gibson (eds.). Cutting propagation: A guide to propagating and producing floriculture crops. Ball Publishing, Batavia, IL.

Farris, M.E., G.J. Keever, J.R. Kessler, and J.W Olive. 2009. Benzyladenine and cyclanilide promote shoot development and flowering of Coreopsis verticillata 'Moonbeam'. J. Environ. Hort. 27:176-182.
Garner, J.M., G.J. Keever, D.J. Eakes, and J.R. Kessler. 1997. Benzyladenine-induced offset formation in hosta dependent on cultivar. HortScience 32:91-93.

Khosh-Khui, M., I. Rouhani, and B. Shaybany. 1978. Axillary shoot stimulation and plant development of coleus treated with certain plant growth regulators. Can. J. Plant Sci. 58:971-976.

Latimer, J.G. and J. Freeborn. 2009. New uses of PGRs in ornamentals: Configure (6-BA) increases branching of herbaceous perennials. Proc. Plant Growth Regulat. Soc. Amer. 36:88-93.

Leclerc, M., C.D. Caldwell, and R.R. Lada. 2006. Effect of plant growth regulators on propagule formation in Hemerocallis spp. and Hosta spp. HortScience 41:651-653.

Martin, S. and S. Singletary. 1999. N-6 Benzyladenine increases lateral offshoots in a number of perennial species. Proc. Intl. Plant Prop. Soc. 49:329334.

McPhee, K. 2005. Variation for seedling root architecture in the core collection of pea germplasm. Crop Sci. 45:1758-1763.

Richards, D. and R.I. Wilkinson. 1984. Effect of manual pinching, potting-on and cytokinins on branching and flowering of Camellia, Rhododendron, and Rosa. Sci. Hort. 23:7583.

Svenson, S.E. 1991. Rooting and lateral shoot elongation of verbena following benzylaminopurine application. HortScience 26:391-392.

Van Staden, J. and A.R. Harty. 1988. Cytokinins and adventitious root formation, p. 185-201. In: Davis, T.D., B.E. Haissig, and N. Sankhla (eds.). Adventitious root formation in cuttings. Dioscorides, Portland, OR. 